\title{
How Effective is Learning Style Material with E-modules During The COVID-19 Pandemic?
}

\section{Dewa Ayu Made Manu Okta Priantini' ${ }^{1}$ Ni Luh Gede Karang Widiastuti²}

\footnotetext{
1,2 Prodi Pendidikan Guru Sekolah Dasar, Universitas Dwijendra, Denpasar, Indonesia
}

\section{ART ICLE INFO \\ Article history: \\ Received April 09, 2021 \\ Revised April 15, 2021 \\ Accepted May 09, 2021 \\ Available online May 25, 2021}

Kata Kunci:

Pengembangan, Bahan Ajar

Digital, Pendidikan Agama

Keywords:

Development, Digital

Teaching Materials, Religious Education

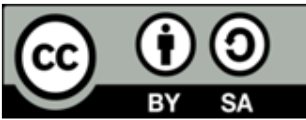

This is an open access article under the CC BY-SA license.

Copyright $@ 2021$ by Author. Published by Universitas Pendidikan Ganesha.

\begin{abstract}
A B S T RAK
Permasalahan yang melatarbelakangi penelitian ini adalah kurangnya sumber belajar bagi siswa pada mata pelajaran IPA sehingga hasil belajar kurang maksimal. Tujuan penelitian ini adalahpengembangan E-Modul pada mata pelajaran IPA materi gaya kelas IV. Penelitian ini merupakan penelitian pengembangan (research and devlopment). Subyek uji coba penelitian adalah siswa kelas IV. Instrumen pengumpulan data yang digunakan berupa lembar evaluasi (angket). Analisis data menggunakan analisis deskriptif kualitatif dan deskriptif kuantitatif. Hasil penilaian terhadap produk e-modul ini dilaksanakan berdasarkan enam aspek, yaitu: aspek isi bidang studi/ dengan persentase tingkat pencapaian $86.00 \%$ dengan predikat layak; ditinjau dari aspek desain pembelajaran dengan persentase tingkat pencapaian $87.60 \%$ predikat layak; ditinjau dari aspek media pembelajaran dengan persentase tingkat pencapaian $89.00 \%$ predikat layak; ditinjau dari aspek uji coba perorangan,dengan persentase tingkatpencapaian $92.50 \%$ pedikat sangat layak; uji coba kelompok kecil, dengan persentase tingkat pencapaian $94.50 \%$ predikat sangat layak;dan ditinjau dari aspek uji coba lapanga dengan persentase tingkat pencapaian $95.50 \%$ predikat sangat layak. Dengan demikian produk berupa e-modul ini memiliki tingkat validitas yang baik dan layak untuk digunakan dalam proses pembelajaran pada materi Gaya mata pelajaran IPA.
\end{abstract}

\section{A B S T R A C T}

The problem behind this research was the lack of learning resources for students in science subjects so that learning outcomes are less than optimal. This research was a research and development (research and development). The research trial subjects were fourth grade students. The data collection instrument used was in the form of an evaluation sheet (questionnaire). The data analysis used qualitative descriptive analysis and quantitative descriptive analysis. The results of the assessment of the e-module product were carried out based on six aspects, namely: content aspects of the field of study / with a percentage of achievement level of $86.00 \%$ with a predicate worthy; In terms of the learning design aspect, the percentage of achievement level is $87.60 \%$, predicate worthy; In terms of the learning media aspect with the achievement level percentage of $89.00 \%$, the predicate is feasible; in terms of the individual trial aspect, with the percentage level of achievement of $92.50 \%$ the predicate is very feasible; small group trial, with the percentage of achievement level of $94.50 \%$, the predicate is very feasible, and in terms of the field trial aspect, the percentage of the achievement level is $95.50 \%$, the predicate is very feasible. Thus the product in the form of e-module has a good level of validity and is suitable for use in the learning process on the subject force material of science subjects.

\section{INTRODUCTION}

The industrial revolution 4.0 is marked by very rapid technological advances throughout the world. This rapid technological progress is marked by almost all community activities using technology systems, including in the world of education. That learning and teaching around the world has gone through a transformation(Getuno et al., 2015; Leal Filho et al., 2018; Shahriar et al., 2021). This transformation can be seen through the presentation of current learning, that the presentation of conventional learning is now supported by teaching materials or materials that utilize technology, information and communication (Santosa et al., 2017). The development of information technology also 
has a very important role for the implementation of learning in schools (Coman et al., 2020; Ghavifekr \& Rosdy, 2015). With this development, an educator is required to further hone, explore his abilities, and be able to take advantage of this information and communication technology, so that it is expected to support progress and change to a more positive aspect in the world of education (Shilpa \& Sunita, 2016). Learning is a process of interaction that occurs between students and learning resources. Good learning is learning that provides opportunities for students to find and explore their own knowledge because by doing their own activities in the learning process students will get more experience that can be used in everyday life(Bressington et al., 2018; Kostiainen et al., 2018). During the current pandemic, educators are required to continue to carry out effective and efficient learning activities by designing their own learning and being able to utilize information technology-based learning media (Coman et al., 2020; Dewa, 2021) 2020). The use of information and communication technology in learning can not only be used at the upper secondary level but also at the elementary school level. This development requires an educator to become a facilitator for students during the learning process which is in line with the objectives of implementing the 2013 curriculum at the elementary school level (Cintang et al., 2017; Wahyudin, 2018). To fulfill obligations as facilitators, educators must be creative in finding media or teaching materials that can be used during learning (Usman, 2016). This is in order to stimulate students' curiosity so that students will be interested in exploring their own knowledge (Herayanti et al., 2017; Johnson, 2017).

Based on the results of observations made at SD Dwijendra, it was found that there were gaps in the learning process which resulted in the learning outcomes of many students who did not meet the minimum completeness criteria, especially in one of the integrated subjects, namely science subjects. There are several problems that occur such as the lack of initiative from the students themselves to explore their own knowledge so that students only accept the knowledge provided by the teacher. This can be caused by the lack of teaching materials that support the implementation of learning. Currently, the existing teaching materials have not been able to develop students' courage and skills in asking questions and opinions(Weriyanti et al., 2020). Currently, the learning process only uses teaching materials, namely student books, which need to be revised and added material according to student needs. Teachers mostly use teaching materials from textbooks which are also combined with general history reading books(Yerizon et al., 2020). If this condition is left unchecked, it will greatly affect the ability of students to understand the material being studied and this will certainly have an impact on learning outcomes. One solution that can be offered is to develop teaching materials based on local wisdom.

Teaching materials are a means that are considered capable of achieving the goals and objectives of the learning objectives (Asriani et al., 2017; Kuswanto, 2019; Martha \& Andini, 2019). Teaching materials that contain an arrangement of learning devices and materials that can create an environment that allows students to learn. Thus, one of the goals of providing teaching materials is to facilitate the student learning process (Ajoke, 2017). Teaching materials can also help teachers in carrying out the process of teaching and learning activities in the classroom (Shabiralyani et al., 2015). Therefore, teachers must be able to choose appropriate teaching materials to be applied in the teaching and learning process to make it easier for students to understand learning materials (Dewa, 2021; Tsai et al., 2017), so that they can achieve the expected learning objectives. The importance of teaching materials in the learning process requires teachers to develop teaching materials that are in accordance with the needs of students, curriculum demands, not depending on textbooks and government aid packages, and according to the characteristics of students (Andani \& Yulian, 2018; Cloonan \& Fingeret, 2020; Weriyanti et al., 2020). Therefore, one of the teaching materials that can be used as a solution is the development of e-modules in science subjects.

Module teaching materials were developed so that students can learn independently (Hamid et al., 2017; Rusmanto \& Rukun, 2020). Modules can be one form of teaching material developed because the module has five main characteristics which are its advantages, namely self-instructional (facilitating independent learning), self contained (loading all material), stand-alone (does not depend on other teaching materials), adaptive, and use friendly (Kimianti \& Prasetyo, 2019). With the development of information technology, it has enabled the development of learning in changing the presentation of teaching materials, in this case the print module, into a module packaged in a digital format or known as an electronic module (E-Modul) (Wirayasa et al., 2020). E-Modul is also a web-based ICT teaching module, its advantages compared to the print module are its interactive nature which makes it easy to navigate, allows displaying/loading of images, audio, video and animation and is equipped with formative tests/quizzes that allow immediate automatic feedback (Pour et al., 2018). The advantage of the E-Modul in the learning process lies in the learning pattern that allows students to learn independently using the EModul and the teacher is no longer the only source of learning for students. The content contained in the E-Modul makes it easier for students to understand the explanation of the material, namely with its interactivity and mixing multimedia elements into E-Modules. The development of teaching materials in 
the form of E-Modules will make it easier for students to understand learning materials. The use of emodules in the implementation of learning can attract students to be more interested and find out the material provided. With this e-module, students can also access and whenever they want to learn because it can be accessed directly through their cellphone. The components of the e-module can also attract students' interest in learning because it contains pictures so that students don't get bored just looking at writing (H. D. Lestari \& Parmiti, 2020).

There are several studies related to this research. Research that states the learning media in the form of e-modules developed in Integrated Science Class VIII was feasible to be used in learning by teachers and students Based on several stages of testing, the interactive module is categorized as valid with a feasibility level of $82 \%$ with good criteria so that the e-module is feasible to use (Kuswanto, 2019; Nursuhud et al., 2019). Research that states that after the e-module media test was carried out the results obtained had very good criteria so that this e-module was feasible to use (Hastari et al., 2019). Research that states that expert assessment and limited trials, problem-based learning-based science e-modules and scientific literacy questions were feasible to be used in science learning to improve scientific literacy skills(Kimianti \& Prasetyo, 2019). Research on teaching materials that have been developed states that teaching materials based on local content/local wisdom can make participants more enthusiastic in participating in learning both at the primary and higher education levels(Hutama, 2016; Kormasela et al., 2020; Nurafni et al., 2020). The development of local script-based teaching materials can improve students' writing skills(Owon, 2017), hone students' language skills (Kimianti \& Prasetyo, 2019)(Saidah \& Damariswara, 2019), be motivated to learn more actively (Lestariningsih \& Suardiman, 2017) . Based on the explanation above, the purpose and focus of this research was the Development of E-Modules on Materials Force in Science Subjects Grade IV SD Dwijendra. The purpose of the study was made to focus researchers on the problems to be tested so that the objectives can be achieved optimally.

\section{METHOD}

This research used the type of research and development (Research and Development). The subjects of this research were media experts, material experts, learning experts, students and teachers. The research used was quantitative and qualitative data types. The collection of data instruments in this research was of interest based on e-module validators of media experts, material experts, and learning experts. As well as teacher and student questionnaires to test the use of e-modules. This development research was a qualitative descriptive data analysis technique using a qualitative assessment, then the quantitative data was calculated the average score. The development model used was the ADDIE model, consisting of the analysis, design, development, implementation and evaluation stages (Tegeh, 2014). This research develops teaching materials used to assist in Hindu religious education courses using teaching materials in the form of e-modules in science subjects. The development of the ADDIE model can be seen in the following chart. The data analysis technique used was qualitative descriptive analysis technique and quantitative descriptive data analysis. Qualitative descriptive analysis techniques were used to process data from the review of content experts in the field of study or subjects, learning product design experts, learning media experts and the results of student trials. The results of this analysis were then used to revise the product developed. While quantitative descriptive analysis was used to process the data obtained through a questionnaire in the form of scores. The results of the data analysis were seen from the results of the high and low percentage of needs desired by the subject who is the target of this research.

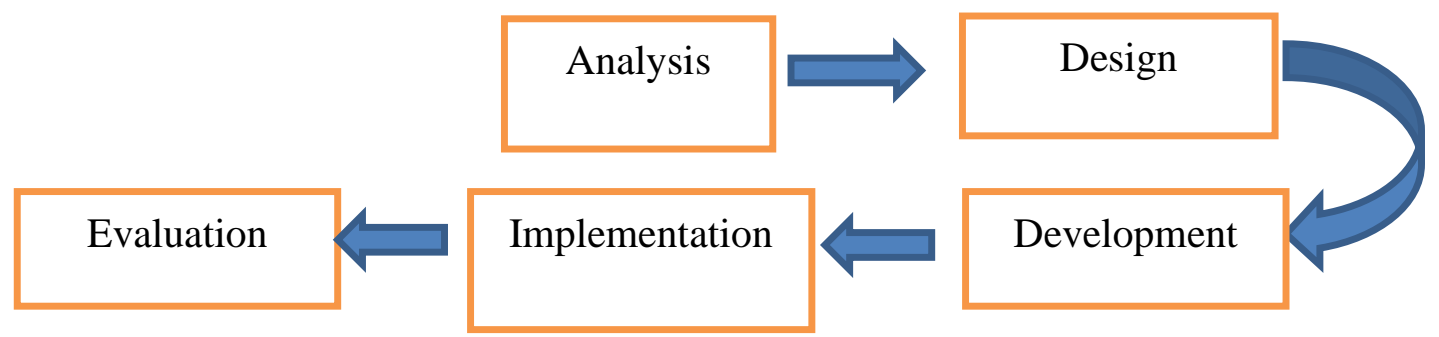

Figure 1. Model Pengembangan ADDIE 


\section{RESULT AND DISCUSSION}

Result

In the development of this E-Module, each stage uses the ADDIE development model by Januszewski and Molenda. The stages in the development model used will be described as follows. The first stage is the Analysis stage (analysis). The initial step taken by the developer in making this E-Module is to make direct observations to SD Dwijendra, which is located in Denpasar City. During the observation activity, the developer tries to dig up information. At this stage the developer can analyze and find out the problems that occur. This is done by giving some questions to the teacher related to the process of implementing learning. After collecting various data and information that can be used as material to strengthen and develop certain products that can be used as solutions to overcome these problems.

The second stage in this development model is design. In general, when making a product, the steps taken are to make a design of the product, in this case, the design made is the design of the e-module. In this stage, the preparation of reference books is carried out first which will be used to support the material in the created e-module, then prepare a concept map, prepare module designs and develop assessment instrument designs. The third stage is development. At this stage the developer has started to develop its product in the form of an e-module based on the design that has been made at the design/design stage. The stages in the development of this product are the media production stage, media validation, and media testing. This research was only carried out until the media trial stage. The calculation of the percentage results from the feasibility test of the developed e-module product shown in Table 1.

Table 1. Instrument Trial Results

\begin{tabular}{lll}
\hline Trial Subject & Validity Results (\%) & Description \\
\hline Subject content expert & 86,00 & Good/ Worthy \\
Learning design expert test & 87,60 & Good/ Worthy \\
Teaching materials expert test & 89,00 & Good/ Worthy \\
Individual trial & 91,50 & Very good/ Very worthy \\
Small Group Trial & 94,65 & Very good/Very worthy \\
\hline
\end{tabular}

Of the five percentages according to the category of very good. So it can be concluded that the EModule media in science subjects, the subject matter of Style developed, is feasible for learning. The next stage is the implementation stage. At the implementation stage, the activity carried out was to assess whether the e-module media developed was to determine the level of effectiveness when used in learning for fourth grade students in Science Subjects for Force Subjects at SD Dwijendra, namely by conducting field trials. This was done by using one class as a test class with a percentage of 95.5 in the very good/very worthy category. The last stage is evaluation. At this stage, what is done is to evaluate the media that has been tested and its feasibility is known. Evaluation and revision can be done simultaneously. Because the feasibility test obtained very good results, this product does not need to be revised and is feasible to use.

The development of a product using the ADDIE development model is deemed capable of meeting standards and product categories that are appropriate to be used to meet teaching materials in the implementation of learning (Cheung, 2016). This can be seen in the elaboration of the results of the feasibility test. In the first stage, namely the Subject Content Expert Test, this product has been tested and assessed by a subject content expert using a questionnaire/questionnaire instrument. After being converted to the benchmark reference assessment conversion table, the level of achievement on a scale of 5 , the percentage of the achievement level is $86.00 \%$ with good/decent qualifications/predicate so that this product does not need to be revised. These results are obtained because the content of the material contained in the e-module is in accordance with the basic competencies and indicators that have been determined.

The second stage is the Learning Design Expert Test. After going through the subject expert test then the product developed is tested on the learning design expert to get assessments, comments, and suggestions on the product in terms of learning design. This teaching material was tested on a learning design expert. After being converted to the Pap conversion table, the level of achievement on a scale of 5, the percentage of the achievement level is $87.60 \%$ with good/decent qualifications/predicates and does not need to be revised. This teaching material is in accordance with the indicators and learning objectives that have been determined, and the presentation of the material presented is simpler to produce teaching materials that are easy to understand and more interesting to learn. In the third stage, the expert test was carried out after the trial of subject content experts and learning design experts. The product in the form of an e-module was tested on a learning media expert. After being converted to a benchmark reference 
assessment conversion table, the level of achievement on a scale of 5, the percentage of the achievement level was $89.00 \%$ with good/decent qualifications/predicate due to the quality of the writing, as well as the pictures on the e-module. -The module is very good and interesting so that the students themselves will also be more interested in learning because they don't only see the writing so that according to the media expert test, this media does not need to be revised.

The fourth stage is a trial for individuals. The subjects used as the subjects of this research were the fourth grade students of SD Dwijendra, totaling 5 students. After being converted to the benchmark reference assessment conversion table, the level of achievement on a scale of 5 , the percentage of the level of achievement is $91.50 \%$ with very good/very worthy qualifications/predicates. This is because the elements that support the teaching materials are appropriate, such as the completeness of the material presented, the selection of simpler words so that they are easier to understand, the selection of subject matter so that the material to be conveyed can be conveyed properly, not boring and can motivate students in learning. and the teaching materials no longer need to be revised. The fifth stage is the Small Group Trial. This trial was carried out after going through the individual trial phase involving 20 respondents or students. The assessment carried out by 20 people is still focused on the material aspect. After being converted to the Pap conversion table, the level of achievement on a scale of 5 , the percentage of the level of achievement is $94.56 \%$ with qualifications/predicates very good/very decent according to the material with the indicators or objectives to be achieved. So this media does not need to be revised.

The last stage is the Field Trial. This field trial was carried out after going through the individual trials and small group trials involving twenty students as respondents. The assessment carried out remains focused on the overall material and media aspects, both physical and non-physical, as well as from the technical aspect of operation. After being converted to the benchmark reference assessment conversion table, the level of achievement on a scale of 5, the percentage of the achievement level is $95.5 \%$ with very good/very worthy qualifications/predicates. So this media does not need to be revised. Based on the stages of the development model that have been carried out, when viewed from the category based on the percentage value that this product is of high quality and feasible to be used in the implementation of learning. But the expert tests provide some notes that can be used as a reference to make a little revision so that the resulting product is better and more effective when used. So that the resulting product is very feasible to use in order to support the effectiveness of the implementation of learning.

Like this teaching material, it is not in accordance with the development steps taken. The analysis stage provides an overview of how the teaching materials are needed in the learning process. From the results of the analysis of the desired teaching materials are teaching materials consisting of interesting images and in accordance with the material. Teaching materials that have interesting pictures will make students interested and interested in reading (Afifah et al., 2016). In addition, from the results of the needs analysis, it was also found that what students currently need are teaching materials that make it easier for students to understand the material being studied as well as teaching materials found by students in everyday life because that is why. The importance of teaching materials in the learning process requires teachers to be able to develop teaching materials that are in accordance with the needs of students, implementing the curriculum, not depending on texts and government aid packages, and in accordance with the characteristics of students(Andani \& Yulian, 2018; Cloonan \& Fingeret, 2020; Mayarnimar \& Taufina, 2017; Weriyanti et al., 2020). With the existence of teaching materials in accordance with the curriculum, needs and characteristics will be able to increase student motivation and students can obtain learning in accordance with the development of science and technology(Suzuki et al., 2020). So, the presence of quality teaching materials will be able to have an impact on motivation, interest, creativity which results in student learning outcomes. Developing materials through teaching materials is the most relevant solution considering the diversity of competencies, creativity, and teaching patterns of teachers in various schools(Suzuki et al., 2020)(Prihandoko et al., 2017).

The e-module created is one of the digital teaching materials that is booming in the world of education today. Teaching materials are all forms of teaching materials used to assist teachers in carrying out the learning process in the classroom which contains a set of materials that are systematically arranged, both written and unwritten, so as to create an environment or atmosphere that allows students to learn in digital form so that they can be accessed. whenever and wherever(Arsanti, 2018; S. Lestari, 2018). Teaching materials that are included in the digital type are good and easy to use because they are more accessible, easy to carry, durable, and easy to obtain for free via the internet (Alperi, 2020). This emodule is considered very suitable to be given to students on material about the style of science subjects. This is because e-modules can be accessed anytime, anywhere students want to learn. During the current pandemic, distance learning is very unlikely for students to get supporting books other than student books. The development of e-modules certainly has a tremendous impact because e-modules have several advantages. These advantages are, among others, because the e-module is structured in the form of 
teaching materials that utilize information technology, so this e-module can save on paper and stationery usage. E-Modules can be arranged with multimedia applications because they can combine various media in the form of text, images, graphics, music, animation, video, and interactions into digital files, and are used to convey messages to users, besides that the amount of teaching time can be reduced and the learning process can be done anywhere and anytime by students independently with e-modules (Artiniasih, et al, 2019).

There are several studies related to this research. Research that states the learning media in the form of e-modules developed in Integrated Science Class VIII was feasible to be used in learning by teachers and students Based on several stages of testing, the interactive module is categorized as valid with a feasibility level of $82 \%$ with good criteria so that the e-module is feasible to use (Kuswanto, 2019; Nursuhud et al., 2019). Research that states that after the e-module media test was carried out the results obtained had very good criteria so that this e-module was feasible to use (Hastari et al., 2019). Research that states that expert assessment and limited trials, problem-based learning-based science e-modules and scientific literacy questions were feasible to be used in science learning to improve scientific literacy skills(Kimianti \& Prasetyo, 2019). Research on teaching materials that have been developed states that teaching materials based on local content/local wisdom can make participants more enthusiastic in participating in learning both at the primary and higher education levels(Hutama, 2016; Kormasela et al., 2020; Nurafni et al., 2020). The development of local script-based teaching materials can improve students' writing skills(Owon, 2017), hone students' language skills (Kimianti \& Prasetyo, 2019)(Saidah \& Damariswara, 2019), be motivated to learn more actively (Lestariningsih \& Suardiman, 2017) This research makes a major contribution to the implementation of learning in schools, especially in science subjects. Based on testing, the developed e-module is feasible to use so that it is ready to be used during learning so that this research has a positive impact on the implementation of learning and can increase students' motivation to learn so that later it will affect student learning outcomes.

\section{CONCLUSION}

This development research resulted in a product in the form of an e-module. The quality of the emodule developed is very good/very worthy. Based on the results of the feasibility test, it can be concluded that the developed e-module is included in the very good criteria. Thus the learning product in the form of an e-module has a good level of validity and is suitable for use in the learning process in science subjects. This e-module will support the student learning process because it can be accessed independently anytime and anywhere.

\section{REFERENCES}

Afifah, E., Triyono, T., \& Hotifah, Y. (2016). Pengembangan Media Letter Sharing Untuk Meningkatkan Keterampilan Komunikasi Siswa Introvert. Jurnal Kajian Bimbingan Dan Konseling, 1(2), 27-32. https://doi.org/10.17977/um001v1i12016p027.

Ajoke, A. R. (2017). The importance of instructional materials in teaching english as a second language. International Journal of Humanities and Social Science Invention, 6(9), 36-44. www.ijhssi.org

Andani, D. T., \& Yulian, M. (2018). Pengembangan Bahan Ajar Electronic Book Menggunakan Software Kvisoft Flipbook Pada Materi Hukum Dasar Kimia di SMA Negeri 1 Panton Reu Aceh Barat. Jurnal IPA \& Pembelajaran IPA, 2(1), 1-6. https://doi.org/10.24815/jipi.v2i1.10730

Arsanti, M. (2018). Pengembangan Bahan Ajar Mata Kuliah Penulisan Kreatif Bermuatan Nilai-Nilai Pendidikan Karakter Religius Bagi Mahasiswa Prodi Pbsi, Fkip, Unissula. KREDO : Jurnal Ilmiah Bahasa Dan Sastra, 1(2), 71-90. https: //doi.org/10.24176/kredo.v1i2.2107

Asriani, P., Sa'dijah, C., \& Akbar, S. (2017). Bahan Ajar Berbasis Pendidikan Karakter Untuk Siswa KElas IV Sekolah Dasar. Jurnal Pendidikan: Teori, Penelitian, Dan Pengembangan, 2(11), 1456-1468. https://doi.org/http://dx.doi.org/10.17977/jptpp.v2i11.10160

Bressington, D. T., Wong, W. kit, Lam, K. K. C., \& Chien, W. T. (2018). Concept mapping to promote meaningful learning, help relate theory to practice and improve learning self-efficacy in Asian mental health nursing students: A mixed-methods pilot study. Nurse Education Today, 60(February 2017), 47-55. https://doi.org/10.1016/j.nedt.2017.09.019

Cheung, L. (2016). Using the ADDIE Model of Instructional Design to Teach Chest Radiograph Interpretation. Journal of Biomedical Education, 2016, 1-6. https://doi.org/10.1155/2016/9502572

Cintang, N., Setyowati, D. L., Sularti, S., \& Handayani, D. (2017). Perception of Primary School Teachers towards the Implementation of Project Based Learning. Journal of Primary Education, 6(2), 81-93. https://doi.org/10.15294/jpe.v6i2.17552

Cloonan, M., \& Fingeret, A. L. (2020). Developing teaching materials for learners in surgery. Surgery 
(United States), 167(4), 689-692. https://doi.org/10.1016/j.surg.2019.05.056

Coman, C., Țîru, L. G., Meseșan-Schmitz, L., Stanciu, C., \& Bularca, M. C. (2020). Online teaching and learning in higher education during the coronavirus pandemic: Students' perspective. Sustainability (Switzerland), 12(24), 1-22. https://doi.org/10.3390/su122410367

Dewa, A. M. M. O. P. (2021). The Development Of Teaching Video Media Based On Tri Kaya Parisudha In Educational Psychology Courses. Journal of Education Technology, 4(4), 448. https://doi.org/10.23887/jet.v4i4.29608

Getuno, D. M., Kiboss, J. K., Changeiywo, J., \& Ogola, L. B. (2015). Effects of an E-Learning Module on Students ' Attitudes in an Electronics Class. Journal of Education and Practice, 6(36), 80-86. https://core.ac.uk/download/pdf/234638271.pdf

Ghavifekr, S., \& Rosdy, W. A. W. (2015). Teaching and learning with technology: Effectiveness of ICT integration in schools. International Journal of Research in Education and Science, 1(2), 175-191. https://doi.org/10.21890/ijres.23596

Hamid, M. A., Aribowo, D., \& Desmira, D. (2017). Development of learning modules of basic electronicsbased problem solving in Vocational Secondary School. Jurnal Pendidikan Vokasi, 7(2), 149. https://doi.org/10.21831/jpv.v7i2.12986

Hastari, G. A. W., Agung, A. A. G., \& Sudarma, I. K. (2019). Pengembangan Modul Elektronik Berpendekatan Kontekstual Pada Mata Pelajaran Ilmu Pengetahuan Sosial Kelas Viii Sekolah Menengah Pertama. EDUTECH Universitas Pendidikan Ganesha, 7, 33-43.

Herayanti, L., Habibi, H., \& Fuaddunazmi, M. (2017). Pengembangan Media Pembelajaran Berbasis Moodle pada Matakuliah Fisika Dasar. Jurnal Cakrawala Pendidikan, 36(2), 210-219. https://doi.org/10.21831/cp.v36i2.13077

Hutama, F. S. (2016). Pengembangan Bahan Ajar Ips Berbasis Nilai Budaya Using Untuk Siswa Sekolah Dasar. JPI (Jurnal Pendidikan Indonesia), 5(2), 113. https://doi.org/10.23887/jpiundiksha.v5i2.8359

Johnson, D. (2017). The Role of Teachers in Motivating Students To Learn Davion Johnson. Journal of Graduate Studies in Education, 9(1), 46-49.

Kimianti, F., \& Prasetyo, Z. K. (2019). Pengembangan E-Modul IPA Berbasis Problem Based Learning Untuk Meningkatkan Literasi Sains Siswa. Kwangsan: Jurnal Teknologi Pendidikan, 7(2), 91. https://doi.org/10.31800/jtp.kw.v7n2.p91--103

Kormasela, D. A., Dawud, D., \& Rofi'uddin, A. H. (2020). Pemanfaatan Kearifan Lokal Maluku dalam Pengembangan Bahan Ajar Menulis Teks Prosedur untuk Siswa Kelas VII. Jurnal Pendidikan: Teori, Penelitian, Dan Pengembangan, 1056-1065. https://doi.org/https://doi.org/10.17977/jptpp.v5i8.13872

Kostiainen, E., Ukskoski, T., Ruohotie-Lyhty, M., Kauppinen, M., Kainulainen, J., \& Mäkinen, T. (2018). Meaningful learning in teacher education. Teaching and Teacher Education, 71, 66-77. https://doi.org/10.1016/j.tate.2017.12.009

Kuswanto, J. (2019). Pengembangan Modul Interaktif Pada Mata Pelajaran IPA Terpadu Kelas VIII. Jurnal Media Infotama, 15(2), 51-56. https://doi.org/10.37676/jmi.v15i2.866

Leal Filho, W., Raath, S., Lazzarini, B., Vargas, V. R., de Souza, L., Anholon, R., Quelhas, O. L. G., Haddad, R., Klavins, M., \& Orlovic, V. L. (2018). The role of transformation in learning and education for sustainability. Journal of Cleaner Production, 199, 286-295. https://doi.org/10.1016/j.jclepro.2018.07.017

Lestari, H. D., \& Parmiti, D. P. (2020). Pengembangan E-Modul Ipa Bermuatan Tes Online Untuk Meningkatkan Hasil Belajar. Journal of Education Technology, 4(1), 73. https://doi.org/10.23887/jet.v4i1.24095

Lestari, S. (2018). Peran Teknologi dalam Pendidikan di Era Globalisasi. Edureligia; Jurnal Pendidikan Agama Islam, 2(2), 94-100. https://doi.org/10.33650/edureligia.v2i2.459

Lestariningsih, N., \& Suardiman, S. P. (2017). Pengembangan Bahan Ajar Tematik-Integratif Berbasis Kearifan Lokal Untuk Meningkatkan Karakter Peduli Dan Tanggung Jawab. Jurnal Pendidikan Karakter, 7(1). https://doi.org/10.21831/jpk.v7i1.15503

Martha, N. U., \& Andini, N. P. (2019). Pengembangan Bahan Ajar Mata Pelajaran Bahasa Indonesia Berbasis Cerita Rakyat Kabupaten Banjarnegara. JINOP, 5(2), 185-197. https://doi.org/https://doi.org/10.22219/jinop.v5i2.9992

Mayarnimar, \& Taufina. (2017). Validity Analysis of the VARK (Visual, Auditory, Read-Write, and Kinesthetic) Model - Based Basic Reading and Writing Instructional Materials for the 1st Grade Students of Elementary School. 118, 870-874. https://doi.org/10.2991/icset-17.2017.141

Nurafni, A., Pujiastuti, H., \& Mutaqin, A. (2020). Pengembangan Bahan Ajar Trigonometri Berbasis Kearifan Lokal. Journal of Medives: Journal of Mathematics Education IKIP Veteran Semarang, 4(1), 
71. https://doi.org/10.31331/medivesveteran.v4i1.978

Nursuhud, P. I., Oktavia, D. A., Kurniawan, M. A., Wilujeng, I., Jumadi, \& Kuswanto, H. (2019). Multimedia Learning Modules Development based on Android Assisted in Light Diffraction Concept. Journal of Physics: Conference Series, 1233(1). https://doi.org/10.1088/1742-6596/1233/1/012056

Owon, R. A. S. (2017). Pengembangan Bahan Ajar Menulis Berbagai Jenis Teks Bertema Kearifan Lokal Sikka Bagi Siswa SMP. Jurnal Inovasi Pembelajaran, 3(1), 528-541. https://doi.org/https://doi.org/10.22219/jinop.v3i1.4318

Pour, A. N., Herayanti, L., \& Sukroyanti, B. A. (2018). Pengaruh Model Pembelajaran Talking Stick terhadap Keaktifan Belajar Siswa. Jurnal Penelitian Dan Pengkajian Ilmu Pendidikan: E-Saintika, 2(1), 36. https://doi.org/10.36312/e-saintika.v2i1.111

Prihandoko, Y., Slamet, S. Y., \& Winarno. (2017). Pendekatan Cognitive Moral Sebagai Kerangka Pengembangan Bahan Ajar Ppkn Di Sekolah Dasar. Jurnal Kependidikan, 1(2), 200-2013. https://journal.uny.ac.id/index.php/jk/article/view/15279/pdf

Rusmanto, R., \& Rukun, K. (2020). The Development of E-Learning Module Based on Project-Based Learning (PjBL) for Electric Motor Installation Course. Journal of Education Research and Evaluation, 4(2), 181. https://doi.org/10.23887/jere.v4i2.24608

Saidah, K., \& Damariswara, R. (2019). Pengembangan Bahan Ajar Materi Dongeng Berbasis Kearifan Lokal Jawa Timur Bagi Siswa Kelas III SD. Premiere Educandum: Jurnal Pendidikan Dasar Dan Pembelajaran, 9(1), 73. https://doi.org/10.25273/pe.v9i1.4320

Santosa, A. S. E., Santyadiputra, G. S., \& Divayana, D. G. H. (2017). Pengembangan E-Modul Berbasis Model Pembelajaran Problem Based Learning Pada Mata Pelajaran Administrasi Jaringan Kelas Xii Teknik Komputer Dan Jaringan Di Smk Ti Bali Global Singaraja. Kumpulan Artikel Mahasiswa Pendidikan Teknik Informatika (KARMAPATI), 6(1), 62. https://doi.org/10.23887/karmapati.v6i1.9269

Shabiralyani, G., Hasan, K. S., Hamad, N., \& Iqbal, N. (2015). Impact of Visual Aids in Enhancing the Learning Process Case Research: District Dera Ghazi Khan. Journal of Education and Practice, 6(19), 226-233. https://files.eric.ed.gov/fulltext/EJ1079541.pdf

Shahriar, S. H. Bin, Arafat, S., Sultana, N., Akter, S., Khan, M. M. R., Nur, J. M. E. H., \& Khan, S. I. (2021). The transformation of education during the corona pandemic: exploring the perspective of the private university students in Bangladesh. Asian Association of Open Universities Journal, ahead-ofprint(ahead-of-print). https://doi.org/10.1108/aaouj-02-2021-0025

Shilpa, S., \& Sunita, M. (2016). A Study an Interactive Elementary Education ( 3-6 ) With Multimedia. International Journal Home Science, 2(1), https://www.homesciencejournal.com/archives/2016/vol2issue1/PartD/2-1-44-761.pdf

Suzuki, S. N., Akimoto, Y., Suzuki, K., Okada, A., Hirata, K., Kato, T., Yajima, K., Kanematsu, H., Fukumoto, T., \& Yoshikawa, F. (2020). Development of A-txt system compatible introductory teaching materials for Electric Power Engineering using gaming simulation. Procedia Computer Science, 176, 1557-1566. https://doi.org/10.1016/j.procs.2020.09.167

Tegeh, M. D. (2014). Model Penelitian Pengembangan. Graha Ilmu.

Tsai, H. C., Jou, M., Wang, J. Y., \& Huang, C. C. (2017). An empirical study on the incorporation of APP and progressive reasoning teaching materials for improving technical creativity amongst students in the subject of automatic control. Computers in Human Behavior, 75, 997-1007. https://doi.org/10.1016/j.chb.2016.10.031

Usman, Y. D. (2016). Educational Resources: An Integral Component for Effective School Administration in Nigeria. Research on Humanities and Social Sciences, 6(13), 1-11. www.iiste.org

Wahyudin, D. (2018). Peace Education Curriculum in the Context of Education Sustainable Development (Esd). Journal of Sustainable Development Education and Research, 2(1), 21. https://doi.org/10.17509/jsder.v2i1.12354

Weriyanti, W., Firman, F., Taufina, T., Taufina, T., \& Zikri, A. (2020). Pengembangan Bahan Ajar Tematik Terpadu dengan Strategi Question Student Have di Sekolah Dasar. Jurnal Basicedu, 4(2), 476-483. https://doi.org/10.31004/basicedu.v4i2.374

Wirayasa, I. D. G. P., Darmayasa, I. P., \& Satyawan, I. M. (2020). Pengembangan Instrumen Penilaian Hasil Belajar Ranah Kognitif Model 4D Pada Materi Sepak Bola Berdasarkan Kurikulum 2013. Jurnal Pendidikan Jasmani Olahraga Kan https://ejournal.undiksha.ac.id/index.php/JJP/article/view/33760

Yerizon, Y., Putri, Y. U., Musdi, E., \& Permana, D. (2020). Efektivitas Perangkat Pembelajaran Matematika Berbasis Pendekatan Contextual Teaching and Learning Terhadap Kemampuan Komunikasi Matematis. AKSIOMA: Jurnal Program Studi Pendidikan Matematika, 9(1), 205. https://doi.org/10.24127/ajpm.v9i1.2305 